\title{
A CORRESPONDÊNCIA DE MARX COM VERA SASSULITCH
}

Os documentos com que Raízes inaugura esta nova seção são duas cartas que permaneceram por longa data esquecidas até por aqueles que protagonizaram aquela correspondência histórica. Aliás, não propriamente esquecidas, mas negadas e ocultas do público que delas deveria ter feito, na época, um uso coletivo e impactante. Esta carta só viria a público, mais de quatro décadas após a morte de Marx, quando a questão, que aquele debate suscitou, já estava "resolvida”!

$\mathrm{Na}$ verdade a solução apresentada pouco difere daquele tipo de solução que o racionalismo-tecnicismo do século XX se tornaria célebre em dar a muitas das questões sociais, culturais e políticas: eliminação física daqueles cuja existência era a própria expressão do problema!

Assim a carta de Marx, que Raízes apresenta a seguir, talvez possa ser tratada como um documento inédito, tal o desconhecimento da existência deste e de outros textos relevantes, que paira entre nós. Na verdade, apesar da existência de uma publicação mexicana da coleção Cuadernos de Pasado y Presente ${ }^{1}$, não se vê referências nos trabalhos publicados sobre a matéria, apesar da importância dada ao referencial marxista nos debates e da relevância da questão agrária e camponesa no Brasil.

Mas o leitor comum se perguntará da oportunidade e pertinência de trazer à luz textos deste autor, Karl Marx, mesmo inéditos, quando parece ter sido provada já insuficiência de sua teoria, pela derrota do socialismo autoritário. Não teria a época de Marx já passado? Não nos cabe aqui fazer toda uma avaliação sobre a propalada crise do marxismo, mas é importante reafirmar que a obra científica de Marx não se resume à sua militância política, nem parece ter tido a chamada "ortodoxia marxista", que se ins- talou na direção dos partidos e movimentos operários após sua morte, uma procuração para falar e predizer a história, em seu nome. Em todo caso, nos parece que muitas das noções vulgares e acadêmicas que circulam a respeito de Marx muito pouco se amparam nos fatos históricos ou em fundamentos teóricos. Em primeiro lugar, em Marx não encontramos apenas soluções, mas a formulação de problemas, de questões, que ainda estão por ser aclaradas. E, para a ciência, as questões são muitas vezes mais relevantes que as soluções. Em segundo lugar, a influência teórica deste autor, principalmente nas ciências sociais, é enorme e bastante difusa, de tal sorte que dificilmente encontramos nestas ciências, debates que de alguma forma não tenham alguma influência do marxismo. Em terceiro lugar, o ambiente acadêmico e científico parece estar hoje muito mais propício a um aprofundamento de sua obra, como nunca esteve antes. Menos oprimido pelo patrulhamento, tão direto e comum há bem pouco tempo atrás, o pesquisador pode pensar e repensar as categorias marxistas sem se preocupar em adequar-se aos cânones impostos pelo partido. Mas concordo que, se é verdade que o ambiente é propício, nem por isso está aberto para inovar seu estilo de leitura e de pensamento. Evidentemente que qualquer novidade não surge à luz sem dificuldades: os consultores e pareceristas estão aí instalados nas editoras oficiais e privadas, vigilantes e atentos para não colocar em risco os dogmas sagrados, os quais ainda que inúteis para o mundo de hoje, justificaram um dia, e acreditam justificar ainda hoje, seu autoritarismo político e intelectual.

As cartas aqui apresentadas nos remetem para uma disputa teórica que, como tantas outras polêmicas no marxismo, não ficou restrita apenas a formulações e a análi- 
ses teóricas. Na verdade, estes debates tiveram enormes implicações políticas para os países do continente europeu, e efeitos não menos graves para as lutas e movimentos de libertação na Ásia, África e América Latina. E estas implicações práticas continuam a existir até hoje, o que faz com os textos aqui apresentados mantenham a sua atualidade, uma vez que podem inspirar novas análises e questionamentos.

Como teoria social, o marxismo não se encontra propriamente em crise, posto que uma verdadeira crise significaria o fracasso total dessa teoria, sua comprovada ineficiência e equivocidade. Por exemplo, as teorias racistas do fim do século XIX e início do século XX entraram em crise, e desapareceram. Uma verdadeira crise para uma teoria significa seu fim como atividade prática, significa que a mesma virou tema para alguns poucos historiadores da ciência e da cultura política. Desta forma, não constituiria mais objeto de debate e interesse próprio, nem seria ponto de partida para nada. Outra é a situação do marxismo, ou mais especificamente, da obra de Marx. Ela é, e continuará sendo, um ponto de partida para interrogações e questionamentos e novas descobertas. Neste sentido, a "crise", se existe alguma, é apenas no sentido de que as afirmações que se tinha como conclusões irretorquíveis se revelaram como questões abertas, como hipóteses a provar e como problemas a serem aprofundados, debatidos e esclarecidos. As noções e formulações, tidas como verdades absolutas ou finais, são na verdade questões e problemas a serem repensados e questionados. Neste sentido, o marxismo não está propriamente em crise, mas representa hoje um novo desafio para o desenvolvimento cientifico das ciências sociais. É mais atual do que nunca.

Normalmente se lê — e comumente se cita - Marx sem respeito ao contexto histórico de sua militância, e sem contextualização do problema específico a que estava afeito naquele momento determinado. Um bom exemplo disso, no campo dos debates sobre o campesinato, são suas análises enfeixadas em um trabalho ocasional, como artigo para uma revista, sobre o golpe de estado na França de 1851, conhecido por seu título, em tradução equivocada, de Dezoito Brumário de Luis Bonarparte. Vulgarmente este texto tem sido tomado como a compreensão essencial de Marx sobre a existência dos camponeses na sociedade capitalista. A publicação das cartas sobre o camponês russo - como também a dos rascunhos que a prepararam, a sair no próximo número de Raízes - tem, antes de tudo, a finalidade de contribuir ao resgate de um Marx histórica e teoricamente multifacetado e desconhecido.
A carta de Vera Sassoulitch a Marx, em fevereiro de 1881, colocava os termos centrais do problema do campesinato na Rússia, problema mais ou menos comum para as sociedades de transição tardia para o capitalismo: Qual é o papel político dos camponeses e de suas organizações nestes paises? No entanto, a colocação do problema por Vera Sassulitch obedece às preocupações de uma militância esquerdista populista, já profundamente dilacerada pelos questionamentos de uma compreensão determinista e economicista da inexorabilidade do processo de transição na Rússia. Na carta de Vera, lemos:

"De duas uma: ou bem esta comuna rural, liberada das exigências desmesuradas do fisco, dos pagamentos aos senhores e da administração arbitrária, será capaz de se desenvolver pela via socialista, isto é, de organizar pouco a pouco sua produção e sua distribuição dos produtos em bases coletivistas. Neste caso, o socialista revolucionário deve sacrificar todas suas forças pela liberação da comuna e por seu desenvolvimento..."

Em termos econômicos, o campesinato russo se encontrava ameaçado pelo avanço do capitalismo. Há dois aspectos, na preocupação de Sassulitch, com conteúdos teóricos diferentes: a) de um lado, o desenvolvimento econômico da própria comuna camponesa russa e a sua resistência à desagregação em função dos efeitos do desenvolvimento capitalista; b) de outro lado, a perspectiva socialista, o desenvolvimento para o socialismo, através da superação social e política da dominação capitalista. Estas duas questões estão coladas, pelo próprio ponto de partida da autora, que sofrera já a influência do pensamento de Marx, que naquela época influenciava todo o movimento de oposição na Rússia. Duas marcas já haviam sido assentadas: o processo econômico em curso, tendente ao capitalismo, e o futuro da sociedade, que deveria marchar inexoravelmente para o socialismo.

Parecia, portanto, que a própria influência da leitura de Marx, e neste momento é particularmente a obra maior de Marx, O Capital, cujo primeiro tomo havia aparecido no início da década de 1870 , na Rússia, estava condicionando um tipo de resposta. Assim, a tendência do movimento socialista russo seria aceitar a inexorabilidade do desenvolvimento capitalista no campo, no estilo da Europa ocidental, e assumir as conseqüências deste fato.

O ponto de vista, portanto, não é simplesmente, "o que está acontecendo" ou "o que poderia acontecer com o camponês", nem tampouco, "quais alternativas teria o campesinato". A questão toda era: qual a perspectiva para o movimento socialista russo, como um movimento universal 


\section{Edgard Malagodi}

diante de um processo inexorável? O que fazia alterar as previsões, e o que viria incomodar profundamente mais tarde os social-democratas russos, era a presença maciça deste campesinato, que constituía a enorme maioria da sociedade russa, o que tornava pessimista a expectativa de uma transição que seguisse o modelo da Europa ocidental.

... "Ou a terra do camponês passará de suas mãos para as da burguesia, em quantos séculos, talvez, o capitalismo chegará na Rússia a um desenvolvimento semelhante àquele da Europa ocidental."

É a existência massiva do campesinato russo que levava os militantes, talvez a contragosto, a examinar o potencial revolucionário do campesinato. Assim, o campesinato, passa a ocupar o lugar central no debate, mas em um contexto de questões que, na verdade, o deslocam para a situação de um elemento subordinado: a importância do campesinato neste processo está secundarizada pela própria compreensão do processo histórico em si, a ser trilhado pela Rússia. Qual a conseqüência social e política, desta ou daquela avaliação do campesinato? Em ambos os casos, as conseqüências são propagandísticas, e dizem respeito à estratégia e tática na mobilização do campesinato.

"Neste caso, eles deverão fazer a propaganda somente entre os trabalhadores urbanos, que se verão continuamente mergulhados na massa de camponeses, os quais seguindo à dissolução da comuna serão atirados ao pavimento das grandes cidades em busca de um salário."

A questão que se colocava para os socialistas russos, para o movimento revolucionário russo, era se havia ou não uma estratégia de transformação social a partir do próprio campesinato, ou a aposta de transformação social deveria toda ela estar concentrada na perspectiva de mobilização do proletariado.

Destaca-se em primeiro lugar que, se esta é uma questão exclusivamente da estratégia socialista, de estratégia revolucionária, ela é dominante em toda a compreensão que os marxistas viriam a elaborar sobre os camponeses. Este é o ponto que é preciso ser ressaltado, e que é específica do debate russo da época, ponto que também separa aquele debate dos debates brasileiros e latino-americanos, tanto nos anos 50 e 60, como hoje. No contexto russo de fins do século XIX a questão é o papel dos camponeses no processo revolucionário, enquanto na América Latina e no Brasil hoje, a perspectiva é a própria inserção e participação dos camponeses na sociedade, quer dizer, na economia, na política e na vida social como um todo.

Mas se esta distância existe e as questões postas são diferentes, não se pode deixar de reconhecer que todo o debate contemporâneo sofre as conseqüências do debate europeu e russo do final do século XIX e início do século XX. Em segundo lugar, uma vez que se produziu um modelo pré-fixado para o campesinato, em função das necessidades táticas e estratégicas do movimento russo e alemão, que tomaram ambos uma perspectiva estritamente proletarista, a sociabilidade própria dos camponeses permaneceu desconhecida. O papel específico do campesinato, de sua resistência e de suas lutas, ficou encoberto. E isso é preciso ser resgatado agora.

O efeito mais difundido daquela compreensão proletarista está na crença da inexorabilidade do desaparecimento do campesinato:

"Ultimamente, temos escutado dizer com freqüência que a comuna rural é uma forma arcaica que a história, o socialismo científico, em uma palavra, tudo o que existe de mais indiscutível, condenam a perecer: As pessoas que pregam isso se dizem seus discípulos por excelência: 'Marxistas'."

$\mathrm{Na}$ literatura brasileira, sobre reforma agrária e sobre pobreza rural, esta convicção ainda está perfeitamente presente. Contra essa literatura, é preciso sustentar, primeiro, que o campesinato não é uma sobrevivência arcaica, e segundo, que a questão agrária é uma questão social relevante e atual, isto é, é relevante na contemporaneidade, para todos os países com características históricas semelhantes à do Brasil. Pois, nem a industrialização urbana — que não pode absorver a forçade-trabalho urbana — nem o agro-negócio - que também não absorve a força de trabalho rural — faz e fará desaparecer a questão agrária. Pode-se dizer, portanto, que, em países como o Brasil, o campesinato subsiste como um segmento social, cultural, econômica e politicamente relevante. Deste ponto de vista, quer dizer, de um ponto de vista que prioriza o aspecto social, cultural e político, e não parte apenas do elemento econômico, há uma questão agrária, que ainda que guarde certas semelhanças com a questão urbana, não é a mesma questão do desenvolvimento econômico. Portanto, existe ainda uma questão agrária e uma questão camponesa a se resolver no Brasil. 


\section{1) CarTa de Vera Zassulitch para Karl MarX}

Tradução E. Malagodi

Genebra, 16 de fevereiro de 1881

Rua de Lausanne ${ }^{\circ} .49$.

A Imprensa Polonesa

Prezado cidadão,

O senhor não desconhece que seu "Capital" goza de grande popularidade na Rússia. Malgrado o confisco da edição, os poucos exemplares que sobraram são lidos e relidos pela massa de pessoas mais ou menos instruída do nosso país; e há pessoas sérias dedicadas ao seu estudo. Mas o que o senhor provavelmente desconheça é o papel que seu "Capital" desempenha em nossas discussões sobre a questão agrária na Rússia e sobre a nossa comuna rural. O senhor sabe, melhor do que ninguém, como é premente esta questão na Rússia. O senhor sabe o que dela pensava Tchernichevsky. Nossa literatura progressista, como os Otiéchestvienhnie Zapiski (Anais Pátrios), por exemplo, continua desenvolvendo suas idéias, mas esta é, a meu juízo, uma questão de vida ou morte, sobretudo para o nosso partido socialista. De uma ou de outra maneira, do senhor depende, sobre esta questão, inclusive o destino pessoal de nossos socialistas revolucionários. De duas uma: ou bem esta comuna rural, liberada das exigências desmesuradas do fisco, dos pagamentos aos senhores e da administração arbitrária, é capaz de se desenvolver pela via socialista, isto é, de organizar pouco a pouco sua produção e sua distribuição dos produtos em bases coletivistas. Neste caso, o socialista revolucionário deve sacrificar todas suas forças pela liberação da comuna e por seu desenvolvimento.

Se, porém, ao contrário, a comuna está destinada a perecer não resta ao socialista, como tal, senão começar a fazer cálculos, mais ou menos mal fundados, para saber em quantos decênios a terra do camponês passará de suas mãos para as da burguesia, em quantos séculos, talvez, o capitalismo chegará na Rússia a um desenvolvimento semelhante àquele da Europa ocidental. Neste caso, eles deverão fazer a propaganda somente entre os trabalhadores das cidades, que se verão continuamente mergulhados na massa de camponeses, os quais seguindo à dissolução da comuna serão atirados ao pavimento das grandes cidades em busca de um salário.

Ultimamente, temos escutado dizer com freqüência que a comuna rural é uma forma arcaica que a história, o so- cialismo científico, em uma palavra, tudo o que existe de mais indiscutível, condenam a perecer. As pessoas que pregam isso se dizem seus discípulos por excelência: "Marxistas". O mais forte de seus argumentos é, freqüentemente: "Foi Marx que disse!"

"Mas como vocês deduzem isso de seu 'Capital'? Nessa obra, ele não trata da questão agrária e nem fala da Rússia”, nós lhes questionamos.

"Marx teria dito isso, se ele falasse de nosso país", respondem seus discípulos de volta, talvez, com demasiada ousadia. Compreende o senhor, portanto, cidadão, a que ponto sua opinião sobre esta questão nos interessa e quão grande o serviço o senhor teria prestado, expondo suas idéias sobre o destino possível da nossa comuna rural e sobre a teoria da necessidade histórica de todos os países do mundo terem que passar por todas as fases da produção capitalista.

Tomo a liberdade de solicitar-lhe, cidadão, em nome de meus amigos, a bondade de nos prestar esse serviço.

Se o tempo não lhe permite de expor a suas idéias sobre estas questões de uma maneira mais ou menos detalhada, tenha ao menos o obséquio de o fazer sob a forma de uma carta que o senhor me permita traduzir e publicar na Rússia.

Aceite, Cidadão, minhas saudações respeitosas,

Vera Zassoulitch.

Meu endereço:

Imprensa Polonesa

Rua de Lausanne num. 49. Genebra.

\section{2) Karl MarX para Vera Zassoulitch}

$$
\begin{array}{r}
\text { Londres, } 08 \text { de Março de } 1881 \\
\text { Maitland Park Road, } 41 \\
\text { London, N.W. }
\end{array}
$$

Querida cidadã:

Uma doença nervosa que me ataca periodicamente, nos os últimos dez anos, me impediu de responder mais cedo à sua carta de 16 de fevereiro. Eu lamento de não poder dar-lhe uma exposição sucinta e destinada à publicação, da questão que você me fez a honra de propor. 


\section{Edgard Malagodi}

Já prometi, há meses, um trabalho sobre o mesmo assunto ao Comitê de São Petersburgo. Entretanto eu espero que algumas linhas serão suficientes para retirar-lhe toda dúvida sobre o mal-entendido em relação à minha suposta teoria.

Analisando a gênese da produção capitalista, eu digo:

"No fundo do sistema capitalista há, portanto, a separação radical do produtor de seus meios de produção... a base de toda esta evolução é a expropriação dos cultivadores. Ela ainda não se completou de uma maneira radical senão na Inglaterra... Mas todos os outros países da Europa ocidental percorrem o mesmo movimento". ("Le Capital", edição francesa, pág. 315 , grifado no original). ${ }^{2}$

A "fatalidade histórica" deste movimento está, portanto, expressamente restrita aos países da Europa ocidental. $O$ porquê desta restrição está indicado nesta passagem do capítulo XXXII [da edição francesa]:

"A propriedade privada, fundada sobre o trabalho pessoal... vai ser suplantada pela propriedade privada capitalista, fundada sobre a exploração do trabalho de outro, pela via do assalariamento." (loc. cit. P. 340)

Neste movimento ocidental trata-se da transformação de uma forma de propriedade privada em uma outra forma de propriedade privada. Entre os camponeses russos teríamos, ao contrário, que transformar sua propriedade comum em propriedade privada.

A análise exposta no "Capital" não oferece, portanto, razões nem a favor, nem contra a vitalidade da comuna rural, mas o estudo especial que dela realizei, e cujos materiais busquei nas fontes originais, me convenceram que esta comuna é o ponto de apoio da regeneração social na Rússia, mas que, para que possa funcionar como tal, seria preciso eliminar primeiramente as influências deletérias que a assaltam de todos os lados e, em seguida, assegurar-lhe as condições normais de um desenvolvimento espontâneo.

Tenho a honra, querida cidadã, de ser seu todo devotado,
Traduzido do volume Marx-Engels-Archiv, vol. 01, Editado por D. Rjazanov, Franfurt a.M. 1925, pags. 316-317 e págs. 341-342.

Karl Marx. 